\title{
EFEK LIKOPEN TERHADAP TIKUS PUTIH GALUR SD (Sprague Dawley) YANG DIINDUKSI \\ PARASETAMOL DENGAN MELIHAT AKTIVITAS \\ SGPT DALAM DARAH
}

\section{EFFECTS OF LYCOPENE ON SD (Sprague Dawley) RAT PARASETAMOL-INDUCED BY DETERMINATION OF AMINOTRANSFERASE (SGPT) ACTIVITY IN BLOOD}

\author{
Risha Maysara, Sapto Yuliani \\ Fakultas Farmasi Universitas Ahmad Dahlan \\ Jl. Prof. Dr. Soepomo, Janturan, Warung Boto, Yogyakarta \\ e-mail :syuliani@yahoo.com
}

\section{Abstrak}

Hepar adalah salah satu organ terpenting yang menjadi tempat utama metabolisme obat di dalam tubuh. Adanya kerusakan pada hepar dapat ditandai dengan kenaikan aktivitas enzim Glutamat Piruvat Transaminase Serum (SGPT) dalam darah. Likopen adalah antioksidan yang mempunyai kemampuan mengeliminasi radikal bebas serta mendetoksifikasi senyawa elektrofilik sehingga kerusakan dapat dicegah. Penelitian ini bertujuan untuk mengetahui apakah likopen dapat mencegah kerusakan hepar oleh parasetamol dengan mengukur aktivitas SGPT pada tikus putih galur Sprague Dawley. Penelitian ini menggunakan 20 ekor tikus jantan galur Sprague Dawley. Hewan uji dibagi dalam 4 kelompok perlakuan. Kelompok I sebagai kontrol sehat (baseline) hanya diberi aquabidest, kelompok II sebagai kontrol sakit diberi parasetamol, kelompok III dan IV sebagai kelompok perlakuan yang masing-masing diberi likopen dengan dosis $15 \mu \mathrm{g} / \mathrm{kgBB}$ dan $30 \mu \mathrm{g} / \mathrm{kgBB}$ selama 21 hari. Pada hari ke-19 kelompok II, serta semua kelompok perlakuan diinduksi parasetamol. Pengambilan sampel darah dilakukan di sinus orbitalis pada hari ke-18 (sebelum diinduksi parasetamol) dan pada hari ke-21 atau dua hari setelah diinduksi parasetamol untuk mengetahui perbedaan aktivitas SGPT. Data yang didapat dianalisis menggunakan metode statistik non parametrik dengan uji Kruskal-Wallis dilanjutkan dengan uji Mann-Whitney dengan tingkat kepercayaan $95 \%$. Hasil penelitian ini menunjukkan bahwa likopen dosis $15 \mu \mathrm{g} / \mathrm{kgBB}$ yang diberikan pada tikus yang diinduksi parasetamol memiliki aktivitas SGPT sebesar 130,10 $\pm 11,83$ U/I dan likopen dosis $30 \mu \mathrm{g} / \mathrm{kgBB}$ memiliki aktivitas SGPT sebesar 106,46 $\pm 2,36$ U/I. Hasil tersebut tidak berbeda bermakna dengan kelompok yang diberi parasetamol saja yang 
memiliki aktivitas SGPT sebesar 92,53 $\pm 2,57$ U/I. Berdasarkan hasil tersebut dapat disimpulkan bahwa likopen dosis $15 \mu \mathrm{g} / \mathrm{kgBB}$ dan $30 \mu \mathrm{g} / \mathrm{kgBB}$ tidak dapat menurunkan nilai aktivitas SGPT pada tikus putih jantan galur Sprague Dawley yang diinduksi parasetamol.

Kata kunci : Likopen, Parasetamol, aktivitas SGPT

\section{Abstract}

Liver is one of the most important organ for drug metabolism in the body. The damage to the liver can be marked by increased activity of the enzyme alanine aminotransferase (ALT) in the blood. Lycopene is an antioxidant that has the ability to eliminate free radicals and detoxifies electrophilic compounds that damage can be prevented. The purpose of this research is to know whether lycopene can inhibit the increase alanine aminotransferase activity of SD (Sprague Dawley) rats induced by parasetamol. This experiment using 20 male rats Sprague Dawley. They were divided into 4 groups. Group I is a healthy control (baseline) was only given aquadest, group II were given paracetamol as pain control, group III and IV are treatment group were each given lycopene with a dosage $15 \mu \mathrm{g} / \mathrm{kg} \mathrm{BW}$ and $30 \mu \mathrm{g} / \mathrm{kg} B W$ for 21 days. On $19^{\text {th }}$ day group II, as well as all treatment groups induced paracetamol. The blood sampling was performed on orbital sinus on $19^{\text {th }}$ day (before induced by paracetamol) and on $21^{\text {th }}$ day or two days after induced paracetamol to know the difference alanine aminotransferase activity. The data were analyzed using non-parametric statistical methods with Kruskal-Wallis test followed by Mann-Whitney test with 95\% confidence level. The result has showed that the lycopene doses $15 \mu \mathrm{g} / \mathrm{kgBW}$ had alanine aminotransferase activity of $130.10 \pm 11.83 \mathrm{U} / \mathrm{I}$ and lycopene doses $30 \mu \mathrm{g} / \mathrm{kgBW}$ had alanine aminotransferase activity of $106.46 \pm 2.36 \mathrm{U} / \mathrm{I}$. If compared with paracetamol control had alanine aminotransferase activity of $92.53 \pm 2.57 \mathrm{U} / \mathrm{I}$, should take a summary that the lycopene doses $15 \mathrm{ig} / \mathrm{kg} \mathrm{BW}$ and $30 \mathrm{ig} / \mathrm{kg} \mathrm{BW}$ couldn't decrease alanine aminotransferase activity on SD (Sprague Dawley) male rats.

Keywords : lycopene, paracetamol, alanine aminotransferase activity 


\section{PENDAHULUAN}

Secara fisiologis organ hepar memegang peranan yang sangat penting yaitu, melindungi tubuh terhadap terjadinya penumpukan zat berbahaya yang masuk dari luar, misalnya obat. Banyak obat yang larut dalam lemak dan tidak mudah diekskresi oleh ginjal. Untuk itu maka sistem enzim pada mikrosom hepar akan melakukan biotransformasi sedemikian rupa sehingga terbentuk metabolit yang lebih mudah larut dalam air dan dapat diekskresikan melalui urin atau empedu.

Parasetamol merupakan obat analgesik antipiretik yang apabila digunakan pada dosis berlebihan atau dalam jangka waktu lama dapat menimbulkan efek toksik pada hepar. Ketika pemakaian parasetamol melebihi batas terapi, jalur glukoronidasi dan sulfatasi menjadi jenuh dan jalur oksidasi sitokrom P-450 menjadi meningkat. Akibatnya NAPQI ( $N$-acetyl- $p$ benzoquinone imine) yang merupakan metabolit toksik dari parasetamol dapat bertahan dengan makromolekul protein sel hepar secara tak terbalikkan sehingga terjadi kematian sel atau nekrosis sel hepar (Davis et al., 1976).

Salah satu antioksidan yang mempunyai kemampuan mengeliminasi radikal bebas tinggi adalah likopen. Likopen yang merupakan salah satu senyawa fitokimia (phytochemical) atau fitonutrien yang bermanfaat bagi kesehatan, seperti senyawa karotenoid lainnya misalnya xantin, lutein, dan lain-lain. (Samosir, 2009).

Likopen sebagai antioksidan nonenzimatis, secara signifikan dapat menurunkan enzim fase I seperti cytochrome p450-dependent enzymes dan meningkatkan enzim detoksifikasi, fase II seperti hepatic quinone reductase (Nguyen and Schwart, 1999). Enzimenzim metabolisme ini penting dalam penghilangan substansi asing dan karsinogen dari dalam tubuh. Enzim tersebut akan mendetoksifikasi senyawasenyawa elektrofilik yang dapat berikatan kovalen dengan protein maupun asam nukleat sehingga kerusakan sel dan inisiasi terjadinya mutasi dapat dicegah. Penelitian ini bertujuan untuk mengetahui apakah likopen dapat mencegah kerusakan hepar oleh parasetamol dengan mengukur aktivitas SGPT pada tikus putih galur Sprague Dawley

\section{METODE PENELITIAN}

\section{Bahan}

Bahan yang digunakan adalah likopen, aquadest, corn oil (minyak jagung), serta parasetamol tablet untuk model hepatotoksikan dan kit-GPT ALAT (glutamic pyruvic transaminase or alanine aminotransferase) (Diasys), yang mengandung : trisbufer $\mathrm{pH}$ 7,5 100 $\mathrm{mmol} / \mathrm{L}$, NADH $0,18 \mathrm{mmol} / \mathrm{L}$. LDH $>$ $120 \mu / \mathrm{L}$ dan 2-oksoglutarat $15 \mathrm{mmol} / \mathrm{L}$ untuk penetapan aktifitas SGPT. Hewan uji yang digunakan adalah tikus putih galur SD (Sprague Dawley).
Alat
Alat yang digunakan antara lain meliputi timbangan hewan, seperangkat alat gelas, magnetic stirer, tabung Eppendorf $5 \mathrm{ml}$, sentrifuge $2500 \mathrm{rpm}$, mikropipet, spektrofotometer UV-Vis mikrolab 300. 


\section{Jalannya Penelitian}

Sebanyak 20 ekor tikus dibagi menjadi 4 kelompok, masing-masing 5 ekor. Selama 21 hari semua kelompok diberi perlakuan. sebagai berikut :

Kelompok I Kelompok kontrol sehat (baseline) yang diberi makan dan minum secara peroral selama 21 hari (kontrol yang tidak mendapatkan perlakuan).

Kelompok II Kelompok kontrol sakit yang diberi corn-oil secara peroral selama 21 hari berturut-turut, dilanjutkan dengan pemberian parasetamol 3 $\mathrm{g} / \mathrm{kgBB}$ dosis tunggal pada hari ke-19.

Kelompok III Kelompok perlakuan yang diberi ekstrak likopen $15 \mu \mathrm{g} / \mathrm{kgBB} /$ hari secara peroral selama 21 hari berturutturut, dilanjutkan dengan pemberian parasetamol $3 \mathrm{~g} / \mathrm{kgBB}$ dosis tunggal pada hari ke-19.

Kelompok IV Kelompok perlakuan yang diberi ekstrak likopen $30 \mu \mathrm{g} / \mathrm{kgBB} /$ hari secara peroral selama 21 hari berturutturut, dilanjutkan dengan pemberian parasetamol $3 \mathrm{~g} / \mathrm{kgBB}$ dosis tunggal pada hari ke-19.

Darah diambil dari sinus orbitalis mata pada hari ke sembilan belas yaitu sebelum diinduksi parasetamol dan pada hari ke duapuluh satu yaitu pada hari kedua setelah diinduksi parasetamol. Darah yang diambil kemudian disentrifus selama 10 menit dengan kecepatan $4000 \mathrm{rpm}$. Serum diambil untuk pengukuran aktivitas GPT-serum mengikuti metode SGPT-ALAT. Pembacaan aktivitas GPT-serum dengan menggunakan alat spektrofotometer UV dengan panjang gelombang $365 \mathrm{~nm}$ dan menggunakan reagen Diasys.

\section{Analisis data}

Dari aktivitas SGPT serum dianalisis secara statistik menggunakan analisis kovarian untuk membandingkan keadaan sebelum dan sesudah perlakuan parasetamol pada masing-masing kelompok. Kemudian perbedaan antar kelompok di uji dengan Kruskal-Wallis dilanjutkan Mann-Whitney dengan taraf kepercayaan 95\% untuk melihat perbedaannya.

\section{HASIL DAN PEMBAHASAN}

Penelitian ini bertujuan untuk mengetahui apakah likopen dapat mencegah kerusakan hepar oleh parasetamol dengan mengukur aktivitas SGPT pada tikus putih galur Sprague Dawley. Berdasarkan pada penelitian sebelumnya (Suhendra, 2009) parasetamol dosis 3 $\mathrm{g} / \mathrm{kgBB}$ dapat menyebabkan terjadinya kerusakan organ hepar setelah 48 jam pemberian parasetamol.

Uji aktivitas SGPT ini dilakukan dengan spektrofotometri UV. Pembacaan aktifitas SGPT didasarkan pada pembacaan $\mathrm{NAD}^{+}$yang spesifik pada panjang gelombang $365 \mathrm{~nm}$. NAD ${ }^{+}$ merupakan hasil reaksi antara piruvat dan NADH yang dikatalis oleh LDH. 
Absorbsi $\mathrm{NAD}^{+}$sebanding jumlah piruvat yang dihasilkan dari reaksi antara L-alanin dan 2-oksoglutarat yang dikatalis oleh SGPT. Jumlah piruvat sebanding dengan SGPT dan aktivitas SGPT dinyatakan dalam U/I (unit/liter).

Pada penelitian ini, pengukuran kadar GPT-serum tiap kelompok dilakukan sebanyak dua kali yaitu, sebelum diinduksi parasetamol dan pada hari kedua setelah diinduksi parasetamol. Hal ini bertujuan untuk mengetahui apakah setelah diberi parasetamol kadar GPTserum mengalami penurunan atau tidak. Adapun nilai rata-rata aktivitas GPTserum tikus putih galur Sprague Dawley pada masing-masing kelompok perlakuan sebelum diinduksi parasetamol dapat dilihat pada Tabel I. terhadap lingkungan, suhu ruangan dan beberapa faktor lain tentunya juga berbeda-beda, yang mana hal tersebut dapat mempengaruhi tingkat stress dari tikus dan akibatnya akan mempengaruhi aktivitas GPT-serum dari masingmasing tikus.

Koay dan Walmsley, (1996) menyatakan bahwa kondisi hepatitis kronis ditandai dengan meningkatnya aktivitas GPT-serum sebesar 2-10 kali dari batas ambang normal. Peningkatan aktivitas GPT-serum pada kelompok perlakuan likopen dosis $15 \mu \mathrm{g} / \mathrm{kgBB}$ dan $30 \mu \mathrm{g} / \mathrm{kgB}$ (Tabel IV) masih tidak melebihi dua kali lebih besar dibandingan dengan batas ambang normal (kontrol sehat), sehingga dapat dikatakan peningkatan yang terjadi masih tidak menandakan terjadinya kerusakan pada sel hepar.

Tabel I. Aktivitas GPT-serum tikus putih galur Sprague Dawley masing-masing kelompok perlakuan sebelum diinduksi parasetamol.

\begin{tabular}{|c|c|}
\hline Kelompok & $\begin{array}{c}\text { Aktivitas GPT-serum sebelum diinduksi parasetamol } \\
\text { (Mean } \pm \text { SE) U/I }\end{array}$ \\
\hline I & $46,73 \pm 9,03$ \\
\hline II & $46,26 \pm 1,59$ \\
\hline III & $70,76 \pm 4,71$ \\
\hline IV & $73,10 \pm 0,87$ \\
\hline
\end{tabular}

Keterangan :

Kelompok I : Kontrol sehat (baseline)

Kelompok II : Kontrol sakit diberi perlakuan corn oil + parasetamol

Kelompok III : Diberi perlakuan likopen dosis $15 \mu \mathrm{g} / \mathrm{kgBB}$

Kelompok IV : Diberi perlakuan likopen dosis $30 \mu \mathrm{g} / \mathrm{kgBB}$

Rata-rata aktifitas GPT-serum sebelum diinduksi parasetamol dosis 3 $\mathrm{g} / \mathrm{kgBB}$ pada masing-masing kelompok perlakuan memberikan nilai yang berbeda-beda. Kemampuan adaptasi tikus
Pengukuran nilai aktivitas GPTserum berikutnya adalah pada hari ke-21. Pada hari ke-21 setiap tikus dari masingmasing kelompok diambil sampel darahnya lagi untuk ditetapkan nilai aktivitas 
GPT-serum setelah diinduksi parasetamol dosis $3 \mathrm{~g} / \mathrm{kgBB}$. Hal ini bertujuan untuk mengetahui apakah setelah pemberian parasetamol dosis $3 \mathrm{~g} / \mathrm{kgBB}$ terjadi penurunan atau tidak pada aktivitas GPT-serum masing-masing kelompok perlakuan dosis likopen.
Pengaruh pemberian ekstrak likopen dapat dilihat dari peningkatan aktivitas GPT-serum (Tabel II) yang semakin menurun apabila dibandingkan dengan kontrol hepatotoksikan. Hal ini berarti semakin besar penurunan aktivitas GPT-serum maka akan semakin

Tabel II. Aktivitas GPT-serum tikus putih galur Sprague Dawley masing-masing kelompok perlakuan setelah diinduksi parasetamol

\begin{tabular}{|c|c|}
\hline Kelompok & $\begin{array}{c}\text { Aktivitas GPT-serum setelah diinduksi Parasetamol } \\
\text { (Mean } \pm \text { SE) U/I }\end{array}$ \\
\hline I & $48,73 \pm 13,26$ \\
\hline II & $92,53 \pm 2,57$ \\
\hline III & $130,10 \pm 11,83$ \\
\hline IV & $106,46 \pm 2,36$ \\
\hline
\end{tabular}

Berdasarkan Tabel II, terlihat bahwa terjadi peningkatan aktivitas GPT-serum secara signifikan pada masing-masing kelompok perlakuan setelah diinduksi parasetamol dosis 3 $\mathrm{g} / \mathrm{kgBB}$ apabila dibandingkan dengan kontrol sehat. Hal ini membuktikan bahwa parasetamol dapat menimbulkan efek toksik pada hepar sehingga menyebabkan kerusakan pada sel hepar yang ditandai dengan meningkatnya nilai aktivitas GPT-serum. baik pula pengaruh pemberian ekstrak likopen atau semakin baik pula efek hepatoprotektif yang dimiliki oleh likopen. Hasil pengujian pemberian likopen terhadap aktivitas GPT-serum pada tikus putih galur Sprague Dawley sebelum dan setelah diinduksi parasetamol dosis $3 \mathrm{~g} / \mathrm{kgBB}$ serta peningkatan aktivitasnya dapat dilihat pada Tabel III.

Tabel III. Aktivitas GPT-serum tikus putih galur Sprague Dawley masing-masing kelompok perlakuan yang diinduksi parasetamol dosis $3 \mathrm{~g} / \mathrm{kgBB}$ pada jam ke-48

\begin{tabular}{|c|c|c|c|}
\hline Kel. & $\begin{array}{c}\text { Aktivitas GPT-serum } \\
\text { sebelum diinduksi } \\
\text { parasetamol } \\
\text { (Mean } \pm \text { SE) U/I }\end{array}$ & $\begin{array}{c}\text { Aktivitas GPT-serum } \\
\text { setelah diinduksi } \\
\text { parasetamol } \\
\text { (Mean } \pm \text { SE) U/I }\end{array}$ & $\begin{array}{c}\text { Peningkatan aktivitas } \\
\text { GPT-serum } \\
\text { (Mean } \pm \text { SE) U/I }\end{array}$ \\
\hline I & $46,73 \pm 9,03$ & $48,73 \pm 13,26$ & $2,00 \pm 14,18$ \\
\hline II & $46,26 \pm 1,59$ & $92,53 \pm 2,57$ & $46,27 \pm 1,37$ \\
\hline III & $70,76 \pm 4,71$ & $130,10 \pm 11,83$ & $59,33 \pm 16,24$ \\
\hline IV & $73,10 \pm 0,87$ & $106,46 \pm 2,36$ & $33,36 \pm 3,23$ \\
\hline
\end{tabular}


Berdasarkan Tabel IV dapat dilihat bahwa aktivitas GPT-serum setelah diinduksi parasetamol dosis 3 $\mathrm{g} / \mathrm{kgBB}$ pada kelompok II (kontrol sakit) menunjukkan nilai sebesar 92, $53 \mathrm{U} / \mathrm{I}$ dengan peningkatan aktivitas GPT-s erum 46,27 U/I ( \pm 2 kali) lebih besar bila dibandingkan dengan kelompok I (kontrol sehat) yang menunjukkan nilai aktifitas GPT-serum 48,73 U/I dan peningkatan aktifitas GPT-serum 2,00 U/I. Hasil dari aktivitas dan peningkatan aktivittas GPT-serum kelompok sakit ini cukup menunjukkan bahwa parasetamol dosis $3 \mathrm{~g} / \mathrm{kgBB}$ dapat menyebabkan terjadinya kerusakan sel hepar tikus pada jam ke-48.

Aktivitas GPT-serum setelah diinduksi parasetamol dosis $3 \mathrm{~g} / \mathrm{kgBB}$ pada kelompok I (kontrol sehat) menunjukkan nilai sebesar 48,73 U/I dan juga mengalami peningkatan aktivitas GPT-serum, yaitu sebesar 2,00 U/I. Terjadinya kenaikan aktivitas GPTserum ini dimungkinkan karena adanya perubahan permeabilitas membran sel sehingga memungkinkan untuk terjadinya kerusakan pada sel hepar.

Aktivitas GPT-serum tikus terinduksi parasetamol dosis $3 \mathrm{~g} / \mathrm{kgBB}$ yang diberi perlakuan ekstrak likopen dosis $15 \mu \mathrm{g} / \mathrm{kgBB}$ (kelompok III) adalah sebesar 130,10 U/I dengan peningkatan aktivitas GPT-Serum 59,33 U/I, sedangkan aktivitas GPT-serum tikus terinduksi parasetamol dosis $3 \mathrm{~g} / \mathrm{kgBB}$ yang diberi perlakuan ekstrak likopen dosis 30 $\mu \mathrm{g} / \mathrm{kgBB}$ (kelompok IV) sebesar 106,46 U/I dengan peningkatan aktivitas GPTserum 33,36 U/I (Tabel VI). Bila dibandingkan dengan kelompok perlakuan yang hanya diberi parasetamol saja (kelompok II) yang aktivitas GPTserumnya 92,53 U/I dengan peningkatan aktivitas GPT-serum 46,26 U/I, terlihat bahwa pada kelompok perlakuan III dan IV belum dapat memberikan efek hepatoprotektor karena belum mampu menurunkan aktivitas GPT-serum dibawah aktivitas GPT-serum pada kelompok perlakuan II (kontrol sakit) dan belum memberikan efek yang lebih besar apabila dibandingkan dengan kelompok perlakuan I (kontrol sehat).

Kelompok perlakuan likopen dosis $30 \mu \mathrm{g} / \mathrm{kgBB}$ (kelompok IV) dapat memberikan peningkatan aktivitas GPTserum yang lebih kecil bila dibandingkan dengan kelompok perlakuan perlakuan likopen dosis $15 \mu \mathrm{g} / \mathrm{kgBB}$ (kelompok III). Bahwa pada aktivitas GPT- serum setelah diinduksi parasetamol dosis 3 $\mathrm{g} / \mathrm{kgBB}$ dengan adanya peningkatan pemberian dosis likopen akan semakin menurunkan nilai aktivitas GPT-serum, sehingga berkemungkinan besar mampu memberikan efek hepatoprotektif apabila dosis pemberian likopen semakin ditingkatkan.

Dari hasil uji Mann-Whitney, pada kelompok kontrol sehat (kelompok I) menunjukkan perbedaan aktivitas GPT-serum yang berbeda bermakna dengan kelompok kontrol sakit (kelompok II). Hal ini menunjukkan bahwa pemberian parasetamol dosis 3 $\mathrm{g} / \mathrm{kgBB}$ dapat menyebabkan kerusakan pada organ hepar. Kerusakan pada organ hepar ini dapat menyebabkan keluarnya produk sekresi yang berupa enzim GPT yang masuk ke pembuluh darah dan kadarnya akan melebihi kondisi normal (kontrol sehat). 


\section{Tabel IV. Hasil uji Mann-Whitney terhadap aktivitas GPT-serum tikus putih galur Sprague Dawley masing-masing kelompok perlakuan setelah diinduksi parasetamol pada hari ke-2}

\begin{tabular}{|c|l|c|l|c|}
\hline No. & $\begin{array}{c}\text { Perlakuan yang } \\
\text { dibandingkan }\end{array}$ & P (signifikansi) & \multicolumn{1}{|c|}{ Keterangan } & $\begin{array}{c}\text { Perbandingan } \\
\text { aktivitas } \\
\text { GPT-serum } \\
\text { antar kelompok }\end{array}$ \\
\hline 1 & Kelompok I-II & $\mathrm{P}<0,05$ & Berbeda bermakna & $1<2$ \\
\hline 2 & Kelompok I-III & $\mathrm{P}<0,05$ & Berbeda bermakna & $1<3$ \\
\hline 3 & Kelompok I-IV & $\mathrm{P}>0,05$ & $\begin{array}{l}\text { Berbeda tidak } \\
\text { bermakna }\end{array}$ & $1=4$ \\
\hline 4 & Kelompok II-III & $\mathrm{P}>0,05$ & $\begin{array}{l}\text { Berbeda tidak } \\
\text { bermakna }\end{array}$ & $2=3$ \\
\hline 5 & Kelompok II-IV & $\mathrm{P}<0,05$ & Berbeda bermakna & $2<4$ \\
\hline 6 & Kelompok III-IV & $\mathrm{P}<0,05$ & Berbeda bermakna & $3<4$ \\
\hline
\end{tabular}

Kelompok kontrol sehat (kelompok I) menunjukkan perbedaan aktivitas GPT-serum yang berbeda bermakna dengan kelompok perlakuan likopen dosis $15 \mu \mathrm{g} / \mathrm{kgBB}$ (kelompok III). Kelompok perlakuan likopen dosis $15 \mu \mathrm{g} / \mathrm{kgBB}$ menyebabkan meningkatnya aktivitas GPT-serum dengan peningkatan yang berbeda bermakna dibandingkan dengan kontol sehat. Hal itu disebabkan karena setiap kelompok hewan uji mendapatkan perlakuan berbeda. Sedangkan pada kelompok perlakuan likopen dosis $30 \mu \mathrm{g} / \mathrm{kgBB}$ (kelompok IV) dengan kontrol sehat (kelompok I) menunjukkan perbedaan aktivitas GPT-serum yang berbeda tidak bermakna $(\mathrm{P}>0,05)$ dengan signifikansi 0,127 . Hal ini menunjukkan bahwa kelompok perlakuan likopen dosis 30 $\mu \mathrm{g} / \mathrm{kgBB}$ meskipun masih meningkatkan aktivitas GPT-serum tetapi peningkatannya tidak berbeda secara nyata atau

tidak begitu signifikan dibandingkan dengan kontrol sehat.

Pada kelompok kontrol sakit (kelompok II) dengan kelompok perlakuan likopen dosis $15 \mu \mathrm{g} / \mathrm{kgBB}$ (kelompok III) menunjukkan perbedaan aktivitas GPT-serum yang berbeda tidak bermakna $(P>0,05)$ dengan signifikansi 0,513 . Sehingga dapat disimpulkan bahwa kelompok perlakuan likopen dosis $15 \mu \mathrm{g} / \mathrm{kgBB}$ tidak memiliki kemampuan untuk menurunkan aktivitas GPT-serum atau tidak memberikan efek hepatoprotektif, karena memiliki jumlah rata-rata peningkatan aktivitas GPTserum yang lebih besar bila dibandingkan dengan kelompok hepatotoksikan (kelompok II). Kelompok perlakuan likopen dosis $30 \mu \mathrm{g} / \mathrm{kgBB}$ (kelompok IV) menunjukkan perbedaan aktivitas GPT-serum yang berbeda bermakna $(\mathrm{P}<0,05)$ dengan kontrol sakit (kelompok II). Hal ini menunjukkan bahwa kelompok perlakuan likopen 
dosis $30 \mu \mathrm{g} / \mathrm{kgBB}$ meskipun masih memiliki kemampuan meningkatkan GPT-serum tetapi peningkatannya berbeda secara nyata dibandingkan dengan kontrol sakit. Karena nilai aktivitas GPT-serum pada kelompok perlakuan likopen dosis $30 \mu \mathrm{g} / \mathrm{kgBB}$ masih lebih besar bila di- bandingkan dengan kontrol
Untuk lebih memperjelas besarnya efek hepatoprotektif yang dihasilkan, maka dihitung persentase efek proteksi (hepatoprotektor) yang dihasilkan oleh hewan uji terhadap aktivitas GPT-Serum. Hasil perhitungan persen proteksi adalah seperti terlihat pada Tabel V.

Table V. Hasil perhitungan \% Proteksi aktivitas GPT-serum kelompok perlakuan dosis terhadap kontrol sakit.

\begin{tabular}{|c|c|}
\hline Kelompok & \% Proteksi Ekstrak Likopen \\
\hline Likopen dosis $15 \mu \mathrm{g} / \mathrm{kgBB}$ & $(+) 28,25 \%$ \\
\hline Likopen dosis $30 \mu \mathrm{g} / \mathrm{kgBB}$ & $(-) 27,88 \%$ \\
\hline
\end{tabular}

Keterangan: $(+)=$ menunjukkan peningkatan $(-)=$ menunjukkan penurunan

sakit sehingga belum dapat memberikan efek optimal dalam menghambat peningkatan GPT-serum.

Hasil uji Mann-Whitney pada kelompok perlakuan likopen antara dosis $15 \mu \mathrm{g} / \mathrm{kgBB}$ dengan dosis $30 \mu \mathrm{g} / \mathrm{kgBB}$ (kelompok III dan kelompok IV) menunjukkan perbedaan aktivitas GPTserum yang berbeda bermakna $(\mathrm{P}<0,05)$ dengan signifikansi 0,050 . Hal ini menunjukkan bahwa pemberian likopen dosis $15 \mu \mathrm{g} / \mathrm{kgBB}$ dan $30 \mu \mathrm{g} / \mathrm{kgBB}$ memiliki kemampuan yang berbedabeda dalam menghambat peningkatan aktivitas GPT-serum. Kedua dosis tersebut memiliki jumlah rata-rata peningkatan aktivitas GPT-serum yang semakin menurun seiring meningkatnya dosis. Kelompok perlakuan likopen dosis $30 \mu \mathrm{g} / \mathrm{kgBB}$ menunjukkan aktivitas GPT-serum yang lebih kecil dibandingkan dengan likopen dosis $15 \mu \mathrm{g} / \mathrm{kgBB}$, walaupun nilai aktivitas GPT-serumnya masih tinggi bila dibandingkan dengan kelompok kontrol sakit.
Berdasarkan Tabel V dapat dilihat bahwa persentase proteksi aktivitas GPT-serum pada kelompok perlakuan likopen dosis $15 \mu \mathrm{g} / \mathrm{kgBB}$ adalah sebesar (+) $28,25 \%$. Hal ini menunjukkan bahwa pemberian ekstrak likopen dosis 15 $\mu \mathrm{g} / \mathrm{kgBB}$ memberikan peningkatan aktivitas GPT-serum terhadap kontrol sakit yang artinya tidak dapat memberikan penghambatan terhadap aktivitas GPT-serum. Kelompok perlakuan likopen dosis $30 \mu \mathrm{g} / \mathrm{kgBB}$ memberikan persentase proteksi aktivitas GPT-serum terhadap kontrol sakit sebesar (-) $27,88 \%$. Hal ini menunjukkan bahwa pemberian ekstrak likopen dosis 30 $\mu \mathrm{g} / \mathrm{kgBB}$ dapat memberikan penurunan aktivitas GPT-serum terhadap kontrol sakit yang artinya berkemungkinan besar dapat memberikan penghambatan terhadap aktivitas GPT-serum. Berdasarkan hasil perhitungan persen (\%) proteksi tampak bahwa kelompok perlakuan likopen dosis $30 \mu \mathrm{g} / \mathrm{kgBB}$ dapat memproteksi kenaikan GPT-serum lebih 
besar daripada kelompok perlakuan likopen dosis $15 \mu \mathrm{g} / \mathrm{kgBB}$.

Berdasarkan hasil analisis data aktivitas GPT-serum di atas dapat disimpulkan bahwa likopen dosis $15 \mu \mathrm{g} /$ $\mathrm{kgBB}$ dan dosis $30 \mu \mathrm{g} / \mathrm{kgBB}$ masih belum dapat menurunkan nilai aktivitas GPT-serum pada tikus putih galur Sprague Dawley yang diinduksi parasetamol dosis $3 \mathrm{~g} / \mathrm{kgBB}$. Namun, likopen dosis $30 \mu \mathrm{g} / \mathrm{kgBB}$ dapat mem- proteksi kenaikan GPT-serum lebih besar daripada kelompok perlakuan likopen dosis $15 \mu \mathrm{g} / \mathrm{kgBB}$. Hal ini kemungkinan karena dosis pemberian likopen yang terlalu kecil. Beberapa penelitian yang berkaitan dengan efek ekstrak likopen dalam tomat terhadap sifat toksik dari parasetamol menujukkan bahwa ekstrak likopen diberikan $5 \mathrm{mg} / \mathrm{kgBB}$ selama 7 hari dapat me- ningkatkan jumlah GSH hati sebesar $\pm 45 \%$ dibandingkan dengan kelompok kontrol. GSH akan berikatan dengan metabolit elektrofil sehingga dapat mencegah terjadinya kerusakan sel hepar (Jamshidzadeh, et al., 2008).

Likopen sebagai antioksidan nonenzimatis, secara signifikan dapat menurunkan enzim fase I seperti cytochrome p450-dependent enzymes dan meningkatkan enzim detoksifikasi, fase II seperti hepatic quinone reductase (Nguyen dan Scwart, 1999). Enzimenzim metabolisme ini penting dalam penghilangan substansi asing dan karsinogen dari dalam tubuh. Enzim tersebut akan mendetoksifikasi senyawasenyawa elektrofilik yang dapat berikatan kovalen dengan protein maupun asam nukleat sehingga kerusakan sel dan inisiasi terjadinya mutasi dapat dicegah (Devi et al., 2011). Inilah yang kemudian menjadi sasaran dari likopen, menurunkan terbentuknya metabolit elektrofil NAPQI yang dihasilkan parasetamol, dan meningkatkan jumlah glutation dalam hati sehingga dapat mendetoksifikasi hepatotoksikan reaktif menjadi tidak reaktif dan kerusakan sel hepar dapat dicegah.

\section{KESIMPULAN DAN SARAN}

\section{Kesimpulan}

Likopen dosis $15 \mu \mathrm{g} / \mathrm{kgBB}$ dan dosis $30 \mu \mathrm{g} / \mathrm{kgBB}$ belum dapat menurunkan aktivitas GPT-serum pada tikus putih galur (SD) Sprague Dawley yang diinduksi parasetamol dosis 3 $\mathrm{g} / \mathrm{kgBB}$.

\section{Saran}

Perlu dilakukan penelitian lebih lanjut dengan melakukan peningkatan dosis likopen untuk mendapatkan dosis optimal hepatoprotektif likopen.

\section{DAFTAR PUSTAKA}

Abubakar, M., 1975, Evaluasi Beberapa Pemeriksaan Laboratorium pada Penyakit Hati, Simposium Mengenai penyakit dalam fak. Kedokteran Universitas Diponegoro, RS. Dr. Karyadi, Semarang.

Agarwal, S., and Rao, A. V., 2000, Tomato Lycopene and Its Role in Human Health and Chronic Diseases - Agarwal and Rao 163 (6) 739 - Canadian Medical Association Journal.htm, Department of Nutritional Sciences, Faculty of Medicine, 
University of Toronto, Toronto, Ont, Diakses 26 Agustus 2009.

Davis, N.G. Harrison, G. Ideo, B. Portmann, D. Labadarios and Roger Williams, 1976, Paracetamol Metabolism in the Rat: Relationship to Covalent Binding and Hepatic Damage, $J$. Xenobiotica, Vol. 6, No. 4 , Pages 249-255

Goodman and Gilman's, 2006, Goodman and Gilman's The Pharmacological Basis of Therapeutics- $11^{\text {th }}$ Edition, Mc Graw-Hill Medical Publishing Division, New York.

Samosir Janji, 2009. Isolasi dan Isomerisasi Likopen dari

SausTomat. Tesis, Sekolah Pasca Sarjana USU Medan

Suhendra G., 2009, Efek Hepatoprotektif Ekstrak Etanol Herba Putri Malu (Mimosa pudica,L.) pada Tikus yang Diinduksi Parasetamol dengan Melihat Kadar SGPT serum, Skripsi, Fak. Farmasi Univ. Ahmad Dahlan

Gupta, K., S., Trivedi, D., Srivastava, S., Joshi, S., Halder, N., Verma, S, D., 2003, Lycopene Attenuates Oxidative Stress Induced Experimental Cataract Development: An In Vitro and In Vivo Study, Nutrition 19:794799, Department of Pharmacology, All India Institute of Medical Sciences, New Delhi, India; and the Department of Ophthalmology, University of Maryland, College Park, Maryland, USA.
Jamshidzadeh A, Baghban M, Azarpira N, Mohammadi Bardbori A, Niknahad H (2008). Effects of tomato extract on oxidative stress induced toxicity in different organs of rats. Food Chem. Toxicol., 46(12): 3612-3615.

Koay, E.S.C dan Walmsley, N., (1996), A Primer of Chemical Pathology, World Scientific Publisher

Nguyen, L.M., J.S Scwart. 1999, Lycopene, Chemical and Biology Properties, J.Food Tech, 53 (2):38-45

Saradha-Devi KM, Annapoorani S, Ashokkumar K (2011). Hepatic antioxidative potential of ethyl acetate fraction of Cynodon dactylon in Balb/c mice. J. Med. Plant Res., 5(6): 992-996.

Treinen-Moeslen, M., 2001, Toxicology of The Liver, in Klassen, D. C., Cassarett \& Doull's Toxicology: The Basic Science of Poisons, 171-179, Mac Millan Pub. Co. Inc., New York.

Vandenberghe, $\quad \mathrm{J}^{\mathrm{a}}$., $\quad 1996$, Hepatotoxixology : Structure, Function and Toxicological Pathology, in Niesink, J. M. R., Vries, dej and Hollimger, A. M., Toxicology Principles and Applications, 671-689, CRC Press inc., USA.

Wyngaarden, J.B, 1982, The Textbook of Medicine, Vol I, 769, WB Saunders Co., Pniladelphia. 